\title{
Family Ownership and the International Involvement of Taiwan's High-Technology Firms: The Moderating Effect of High-Discretion Organizational Slack
}

\author{
Yunshi Liu, ${ }^{1}$ Wen-Ting Lin, ${ }^{2}$ and Kuei-Yang Cheng ${ }^{3}$ \\ 'National Yunlin University of Science and Technology, Taiwan, ${ }^{2}$ National Chung Cheng \\ University, Taiwan, and ${ }^{3}$ National Taizwan University, Taiwan
}

ABSTRACT This study examined the combined effect of family ownership and highdiscretion organizational slack on the international involvement of Taiwanese firms. Employing a sample of 179 publicly listed high-tech firms in Taiwan over a period of 6 years (2000-2005), we found that firms with high levels of international involvement, that is, a higher degree of internationalization, (i) were not closely held, and (ii) were not excessively controlled by the family. Further, high-discretion organizational slack (indicated by resources that can be deployed in a flexible fashion such as in cash and receivables) moderated the negative relationship between family control and international involvement. This relationship is stronger with a higher level of high-discretion slack. The results support the hypothesis that family control and high-discretion organizational slack negatively influence the decision to internationalize.

KEYwORDs family control, family ownership, international involvement, organizational slack

\section{INTRODUCTION}

The business world continues to globalize. No longer limited by geography or national boundaries, companies of all sizes and most industries are 'going global' (Bartlett \& Ghoshal, 1989; Hordes, Clancy, \& Baddaley, 1995; Javidan \& House, 2002). Sapienza, Autio, George, and Zahra (2006) point out that the internationalization of firms is perhaps the most profound business phenomenon of the 20th century. In recent years in Taiwan, the volume of international trade and foreign direct investment (FDI) has approached 50 percent of the gross national product (Chang, 2007). According to Lien, Piesse, Strange, and Filatotchev (2005: 742), between 1991 and 1995 the average annual outward FDI from 
Taiwan was USD 24.5 billion, or nearly 1 percent of global outward FDI. From 1995 to 2000, the average annual outward FDI from Taiwan almost doubled, reaching USD 48.1 billion. In addition, the average annual ratio of foreign sales to total sales in Taiwan increased from 41.95 percent between 1999 and 2003 to 45.41 percent between 2004 and 2008. ${ }^{[1]}$ These data indicate an increase in the internationalization of Taiwanese firms. It is important for firms in Taiwan and other newly industrialized economies (NIEs) to expand globally because they have a greater need for legitimacy and resources in the international context (Contractor, Kumar, \& Kundu, 2007). However, most previous international business studies are set in the context of multinational enterprises originating in developed economies (Ramamurti, 2004), owing to the short history of internationalization of high-tech firms in the NIEs. The Taiwanese high-tech industry provides a rich context to explore internationalization, given its high rate of increase of these firms' international involvement in recent years. Specifically, the current study considers the factors that may affect the degree of internationalization.

During the 1990s Taiwan achieved great success in the information technology industry. Today, Taiwanese high-tech firms are clearly becoming a major player in the global high-tech industry. For example, Acer is the third largest global computer manufacturer and Taiwan Semiconductor Manufacturing Company is the world's largest dedicated semiconductor producer. Foxconn is a family-owned and -controlled company that has emerged as the world's largest handset manufacturing services provider. In terms of export value, Taiwan's high-tech industry has surpassed the textile and apparel industries - traditionally the core industries in the Taiwanese specialization model - to become the leading export sector since 1994. Taiwanese high-tech firms usually have a complicated structure of ownership and control, which includes substantial family ownership, management ownership, and domestic/foreign institutional ownership. Family control, concentrated ownership, limited activism by institutional investors, and the lack of bank monitoring result in family leaders dominating the corporate governance environment in Taiwan. The specific characteristics of this model of corporate ownership and control are particularly dominant in Taiwanese high-tech firms. ${ }^{[2]}$

There are a variety of factors that may affect a firm's internationalization (e.g., Hitt, Tihanyi, Miller, \& Connelly, 2006), including financial resources due to institutional ownership (Tihanyi, Johnson, Hoskisson, \& Hitt, 2003), external information due to relational networks (Araujo \& Rezende, 2003), and firm-owned human resources (Hitt, Bierman, Uhlenbruck, \& Shimizu, 2006). Recently research has begun to explore how family-owned businesses are managed and how such management influences decisions regarding internationalization (Erdener \& Shapiro, 2005; Fernández \& Nieto, 2006; Graves \& Thomas, 2006; Lu, Liu, \& Wang, 2011; Zahra, 2003). Very few empirical studies have examined the 
influence of the family factor on the FDI or entry-mode decisions of most East Asian firms (e.g., Chai \& Rhee, 2010; Filatotchev, Strange, Piesse, \& Lien, 2007; Lien et al., 2005). There remain three pivotal gaps in the literature. First, these studies fail to capture the essence of the stage model of internationalization theory (Johanson \& Vahlne, 1977). The stage model regards internationalization as an incremental learning process. Its measurement should take into account the scale and scope of a firm's international involvement. ${ }^{[3]}$ Second, findings on the impact of family control ${ }^{[4]}$ are limited. Finally, and most importantly, the existing literature concludes that family businesses have played a major role in Taiwan's economic development and the characteristics of family-owned businesses are appropriate for the success of traditional manufacturing firms. However, Taiwan's economy has been transformed from traditional manufacturing industries to technologyintensive industries. In this high-risk, rapidly changing business environment, short product life cycles associated with the high-tech industry place pressure on firms to internationalize. It remains to be seen whether family businesses that facilitated past successes will continue to succeed in an increasingly global, high-technology industry (Carney, 1998, 2005). Thus, the first objective of this study is to explore the relationship between family ownership and internationalization among Taiwan's high-tech firms.

International business theories highlight the significant influence of organizational resources when expanding across borders (Lu \& Beamish, 2001). Organizational resources serve as inducements for firms to experiment, take risks, and make proactive strategic choices (George, 2005). In the organizational theory literature, slack resources may facilitate strategic behaviour that allows firms 'to experiment with new strategies by, for example, introducing new products, entering new markets, and so on' (Bourgeois, 1981: 35). However, Jensen and Meckling (1976) posit that surplus resources can also induce self-serving managerial behaviour. Managers with surplus resources may resist change and embrace the strategic status quo that ensures their financial security or power. Foreign expansion that entails substantial risk may be unattractive to managers with surplus resources. Thus, the second purpose of this research is to investigate how a firm's slack resources may influence the relationship between family control and the internationalization of Taiwanese high-tech firms.

This study makes two contributions to international business and family business literature. First, it provides knowledge on the controlling family's impact on the firm's internationalization process in high-tech firms in Taiwan that are representative of firms in NIEs. Taiwanese companies are recognized as an 'important research laboratory' for developing corporate research (Filatotchev, Lien, \& Piesse, 2005: 258). Second, the study identifies a contingency - that is, organizational slack - that may further dampen Taiwan's high-tech firms' desire to internationalize when they have excess family control - controlling family's voting rights in excess of its cash-flow rights. 


\section{LITERATURE AND HYPOTHESES}

Much of the literature on strategy or organization theory concludes that the ownership structure can affect a firm's internationalization (e.g., George, Wiklund, \& Zahra, 2005; Sanders \& Carpenter, 1998) because different owners have different values, incentives, and temporal preferences. Agency theory highlights that as ownership increases, the owner and the firm achieve a greater alignment (Fama \& Jensen, 1983; Jensen \& Meckling, 1976). The alignment of interests between the firm and the family owner will contribute to the pursuit of risky activities such as going international (Zahra, 2005). This is because owner-managers often have longer time-horizons than non-family firms (Bruton, Ahlstrom, \& Wan, 2003) to enhance business growth, create opportunities for their children, and protect the family firm from aggressive competitors (Poza, 2004). However, the existing empirical literature examining the influence of family ownership on firm decisions and international strategy reveals mixed results. For instance, Zahra (2003), in a study of manufacturing firms in the U.S., finds that family involvement or ownership is positively related to firm expansion across national borders. In contrast, Fernández and Nieto (2006), using a sample of Spanish manufacturing firms, found that there is a negative correlation between family ownership and the internationalization of these firms.

\section{The Influence of Family Ownership and Control on International Involvement}

Previous international business scholars have proposed that the extent of a firm's international involvement includes three elements: performance, structural, and attitudinal elements (Sullivan, 1994). The first element, performance, indicates a firm's dependence on foreign markets, commonly measured by forcign sales. The structural element gauges a firm's resources located overseas, commonly measured by foreign assets. The performance and structural elements reflect the depth or scale of a firm's internalization involvement. The attitudinal element appraises the breadth or scope of a firm's internationalization (Thomas \& Eden, 2004), which addresses the international orientation of top management or the cultural dispersion of international involvement, commonly determined from geographic dispersion. In this study, we define international involvement as the extent to which a firm's earnings are derived from operations and activities conducted overseas.

We argue that family control will have a negative impact on the international involvement of high-tech firms for three reasons. First, family firms tend to become risk-averse while the family's investments are undiversified (Donckels \& Frohlich, 1991; Fama \& Jensen, 1985; Jensen \& Meckling, 1976). Since high family shareholdings suffer from an undiversified financial portfolio and constrained liquidity (Anderson \& Reeb, 2003), family wealth may be more adversely affected by specific 
risks than other shareholders, such as institutional investors with diversified portfolios (Maug, 1998). With the family's wealth so closely tied to the company's expansion strategy and because internationalization poses risks and uncertainties, the family may take a conservative stance regarding internationalization activities and may be unwilling to undertake large-scale investments in distant places (Chandler, 1990). Second, Taiwan is thought to be highly family-oriented (Chen, 2001). The family business model carries an institutional logic of family control. In Taiwan, family members usually strongly identify with their firms and view the firms as extensions of their families. Thus, with the intention of passing the firms on to successive generations (Yeh \& Tsao, 1996), the owners of Taiwanese family firms are reluctant to relinquish control to outsiders (Begley \& Tan, 2001). Family leaders are also inclined to resist expanding their business overseas to avoid some foreign activities, especially entry modes via joint ventures, mergers, or acquisitions, which may dilute family control (Schulze, Lubatkin, Dino, \& Buchholtz, 2001).

Third, the characteristics of family firms may hinder the growth of businesses and may become liabilities in managing large-scale, technologically complex industries (Garney, 1998). The governance structure of family firms embodies paternalistic, centralized decision-making, and less formalized organizational structures that generate parsimony and efficiency advantages in low-tech manufacturing and trading industries. However, in high-tech industries, where the environment is much more dynamic, uncertain, and complex, high-tech firms require a professionalized management structure to establish complex coordination systems and to decentralize decision-making so as to recognize and respond to changes in the environment. Centralized decision-making, distrust of outside professional managers, and the simple organizational structure may limit the firm's ability to carry out complex international tasks. Ahlstrom, Young, $\mathrm{Ng}$, and Chan (2004) found that Taiwanese high-tech entrepreneurs adopt most of the traditional characteristics of family firms, and it is these traditional features and practices of family firms that may prevent them from achieving international growth (Carney, 2005).

Together, the concern with family wealth preservation, the desire for family control, and the adoption of a traditional managerial culture, the international expansion of high-tech family firms will likely be limited. Based on the above reasoning we hypothesize:

Hypothesis 1: Family owenership will be negatively associated with a firm's international involvement.

In Taiwan, family firms usually establish a highly concentrated ownership structure through pyramid structures and cross-holdings within the family group (Claessens, Djankov, \& Lang, 2000; Yeh, Lee, \& Woidtke, 2001). Pyramid structures are formed when a firm owns equity stocks of another corporation, 
which in turn holds shares of another firm. This process of ownership extension can be repeated several times (La Porta, Lopez-de-Silanes, \& Schleifer, 1999) and we refer to this as 'excessive ownership control'. As an example, a family owns a 10 percent share of firm A, and firm A holds 20 percent of the ownership of firm B. By structuring their investments in this way, the family can control 20 percent of the voting shares of firm $B$, even if it only holds a 2 percent $(10$ percent $\times 20$ percent $=2$ percent) stake in the firm. Villalonga and Amit (2006), Claessens, Djankov, Fan, and Lang (2002), and Lins (2003) also observe this phenomenon of excessive family control in their studies on the economic structure of East Asian societies. They find that the family has effective control over investment decisions in many companies and may channel these resources toward their own interests (La Porta et al., 1999). It is expected that such tightly held and managed family firms will choose to expand operations locally rather than to pursue high-risk foreign market investments, thus avoiding the possibility of expropriation by outside investors. This strategy not only enables them to gain control over resources but also ensures the control of firm operations.

\section{Hypothesis 2: Excess family control will be negatively associated with a firm's international involvement.}

\section{The Influence of Organizational Slack on Family Ownership and Internationalization}

When a firm increases its global activities, it will not only create more competitive challenges, but also encounter more managerial complexity (Carpenter \& Fredrickson, 2001). The firm will need resources to deal with complex informationprocessing demands. Firms with organizational slack are able to compete more successfully in such an environment and can adapt more quickly to the complex and competitive landscapes (Cyert \& March, 1963; Levinthal, 1997). Organizational slack serves as a buffer to protect the firm's core from any changes within the global environment, while, at the same time, enabling it to exploit foreign market opportunities. Firms have opportunities to experiment with new strategies when there is a fair amount of slack (Bourgeois, 1981). These strategies can include the introduction of new products, staging entries into new markets, and going global.

However, organizational economists challenge the benefits of maintaining slack. In spite of their inability to acquire and access the necessary resources (MacMillan \& McGrath, 1997), firms without slack continue to embrace and pursue the new opportunities (Baker \& Nelson, 2005; George, 2005) brought about by the changing business environment. Thus slack deficient firms are more likely to seek their resources more efficiently (George, 2005). However, other theories may support the argument that slack deficient firms may also be more aggressive in their internationalization efforts by cautiously planning to minimize uncertainty and risks. 
First, based on the economic rationality norm, the costs for failing to engage in foreign market expansion is expected to be higher for firms with limited organizational slack. Second, from an agency perspective, slack may encourage political or self-aggrandizing managerial behaviour that may be harmful to the firm (Bourgeois, 1981). For instance, a firm that has organizational slack is less likely to hire professional managers with international experience because it is reluctant to relinquish control. Third, prior studies report that managers are more likely to relax their hold on foreign market expansion when the firm's slack levels exceed those of its competitors. Smith, Grimm, Gannon, and Chen (1991) depict a negative relationship between available slack and competitive responses. They argue that slack serves as a buffer, and firms with more liquid resources are subject to less competitive pressures. Therefore, organizational slack serves to limit managerial incentive to expand aggressively including internationally.

To examine how organizational slack may influence the international involvement of family-owned firms, it is important to consider high-discretion organizational slack, which is slack that can be deployed in a flexible fashion, such as in cash and receivables (Bourgeois, 1981; Bourgeois \& Singh, 1983; Sharfman, Wolf, Chase, \& Tansik, 1988). If organizational slack cannot be deployed in a flexible manner because it is absorbed into the organization, such as in debt or fixed assets, the slack is referred to as low-discretion organizational slack. High-discretion organizational slack can be easily redeployed and is readily available to support new foreign initiatives. However, low-discretion organizational slack is absorbed into the cost structure of the firm, and thus is not available for discretionary use. High-discretion organizational slack is essential when a firm expands across borders, involving large amounts of cash outlays.

Past research highlights the relevance of organizational slack to the controlling power of family members. Kim, Kim, and Lee (2008), for example, find that family members can use slack to pursue power, prestige, money, and job security and then to engage in empire-building. The controlling power of family members can be increased by holding the slack, especially high-discretion organizational slack. As a result, monitoring by non-family minority shareholders and boards of directors might become ineffective among high-power family majority shareholders. In this situation, family members can increase self-interested behaviour and impede a firm's international activities, because they fear that in the process of international involvement they may lose their existing power by expanding the highdiscretionary slack. Consequently, high-discretion organizational slack exacerbates the negative relationship between family control and firm internationalization. Thus, we propose:

Hypothesis 3a: Family ovenership of a firm will be more negatively associated with a firm's international involvement when there is more high-discretion slack. 
Hypothesis 3b: Excess family control of a firm will be more negatively associated with a firm's international involvement when there is more high-discretion slack.

\section{METHOD}

\section{Sample}

To test our hypotheses, we used data collected from public firms in the high-tech industry because most of these firms are moving in the direction of further international expansion and have established overseas markets for their products. The sample for this study was drawn from a population of Taiwan's high-technology public firms that were listed in the Taizean Economic Joumal (TEJ) database for six consecutive years. First, we identified 306 high-technology firms in the TEJ. Second, we selected a 6 year window (2000-2005) because slack may be accumulated and deployed over time, and the firm's international process may evolve over a rather lengthy period. This window also maximized the number of firms reporting financial data for contiguous years, thus yielding a usable sample of 179 firms (1,074 observations). We incorporated a 1 year lag between the dependent variable and the independent variables in order to avoid endogeneity. Thus, the values for the dependent variable (international involvement) covered 2001 to 2006, and those for the independent variables covered 2000 to 2005. Third, data regarding foreign assets and the number of countries in which a firm has subsidiaries were obtained from the Market Observation Post System, and the data on foreign sales, organizational slack, family ownership, and family control were collected from the TEJ database.

\section{Measurement}

Dependent variable. Following Sullivan (1994), we measured a firm's international involvement using three distinct dimensions. ${ }^{[5]}$ The first dimension, foreign sales, is the ratio of foreign sales to total sales (Geringer, Beamish, \& da Costa, 1989). The second dimension, foreign production, reflects the firm's reliance on its foreign stocks and it is measured by calculating foreign assets as a percentage of total assets (Daniels \& Bracker, 1989). ${ }^{[6]}$ The third dimension, geographic dispersion (Sullivan \& Bauerschmidt, 1989), gauges the number of countries in which a firm has subsidiaries and it is expressed as a percentage of the highest number of countries with subsidiaries represented in the study sample (Sanders \& Carpenter, 1998). The range for each of these three dimensions is between 0 and 1 . We found that these three variables loaded onto one factor with a high eigenvalue. ${ }^{[7]}$ We summed these three dimensions and formed a composite measure of the degree of the firm's international involvement, giving it a measurement range from 0 to 3 .

Independent variables. Following Villalonga and Amit (2006), family owership was measured as the ratio of the number of shares held by the family over the total 
number of outstanding shares. ${ }^{[8]}$ According to La Porta et al. (1999), excess family control is defined as the difference between family voting rights and family cash flow rights, which is measured as the difference between the percentages of all outstanding votes by the family and the percentage of all outstanding shares owned by the family.

Moderating variable. We chose to follow the financial indicators adopted in prior studies (c.g., George, 2005) to measure the moderating variable of high-discretion slack. It is the level of the current ratio (current assets/current liabilities). This proxy corresponds to the currently uncommitted slack, such as idle working capital. A higher current ratio indicates a greater ability to meet immediate resource needs.

Control variables. The present study includes six control variables: firm age, firm size, firm performance, diversification degree, non-family executive ownership, and R\&D ratio. Findings by Yip, Biscarri, and Monti (2000) reveal that older firms have relatively greater international market commitment and organizational resources, hence such firms have a higher level of international involvement. First, firm age, calculated as the number of years since incorporation, is included as a control. Second, firm size is typically related to the extent of its international involvement and indicates a strong capability and an abundance of resources to deal with all types of complex foreign information (Henderson \& Fredrickson, 1996). The logarithm of the firm's assets in a given year was used as an independent control for firm size. Third, since poor performance may limit a firm's ability to enter foreign markets (Tihanyi, Ellstrand, Daily, \& Dalton, 2000), we controlled for prior performance, as measured by ROA. Fourth, according to Sanders and Carpenter (I998), diversification is positively related to a firm's global strategic posture. Thus, we controlled the firm's diversification by using the Herfindahl-Hirschman index. Fifth, a non-family executive can be a source of professional knowledge and financial resources. Accordingly, a firm with non-family executives who have high ownership is likely to enter the international market (Musteen, Datta, \& Herrmann, 2009). Therefore, in this study we include non-family executive ownership as a control variable. Nonfamily executive owerersip was measured as the ratio of number of shares held by the $\mathrm{CEO}$ and the top managers who are not members of the largest shareholder over the total number of outstanding shares, thus modifying the measurement by Filatotchev et al. (2007). Sixth, we controlled for the $R \mathcal{E} D$ ratio, which was measured as the ratio of R\&D expenditure divided by total firm sales (Filatotchev \& Piesse, 2009).

\section{Analytical Approach}

Our hypotheses were tested using repeated observations of the same set of crosssectional units (i.e., panel data) (Greene, 2000). A random effects model was used to analyse the panel data because the alternative dummy variable approach is costly in terms of losing a degree of freedom. However, it is crucial to perform a 
Hausman test for the orthogonality of the random effects before the individual effects can be treated as random. This test assesses the consistency of the estimation results of a fixed effects model with a random effects model. In the event that the two estimates do not differ systematically, a random effects generalized least squares (GLS) regression is generally preferable because it is a significantly more efficient estimation technique (Greene, 2000: 576). In our sample, the Hausman test indicated that the estimation results of the fixed effects and random effects model were consistent, and the individual effects were not correlated with the other variables in the model. Therefore, we employed the more efficient random effects GLS estimation technique.

The GLS approach does not allow for calculations of the variance inflation factor (VIF). The VIF is derived using an ordinary least squares regression [which is more conservative than the GLS for the VIF because it does not control for the firm and year; the modest correlations between the independent variables suggest that multicollinearity problems are unlikely to occur (the highest VIF was 2.75, well below the benchmark of 10)]. We took additional actions to avoid these problems by centring the variables used to test the predicted interactions (Aiken \& West, 1991).

\section{RESULTS}

The means, standard deviations, and bivariate correlations for all the variables are presented in Table 1. The table shows that the mean degree of internationalization of Taiwanese high-tech firms is 0.98 . The minimum value is 0 and the maximum value is 2.74 .

Table 2 shows the coefficient estimates for the main effect of family ownership as well as interaction effects of organizational slack on family ownership or excessive family control and international involvement. As the base model, the first model contains all of the control variables. The second model includes both the main and control variables. In the third and fourth models, the interaction variables are entered into the regressions one at a time. The fifth model is the full model, which includes the main, control, and all interaction variables. Centred values of the variables are used for the estimation of the main effect and interaction effect models (i.e., Models 2 to 5). The Wald chi-square statistic indicates the overall significance of each model, and the second chi-square change statistic provides a test for the statistical significance of the added variables in a particular model. The chi-square statistic of Model 2 for change, compared to the control effect (i.e., Model l) is significant $\left(\Delta \chi^{2}=10.27, \mathrm{p}<0.001\right)$. The chi-square statistic of Model 3 for change compared to the main effect (i.e., Model 2) is not significant, but the chi-square statistic of Model 4 for change compared to the main effect (i.e., Model 2 ) is significant $\left(\Delta \chi^{2}=11.36, p<0.001\right)$. Model 1 shows that the two control variables with significant effects on a firm's international involvement are firm size $(\mathrm{p}<0.01)$ and firm performance $(\mathrm{p}<0.01)$. Using Model 2 to examine Hypotheses 


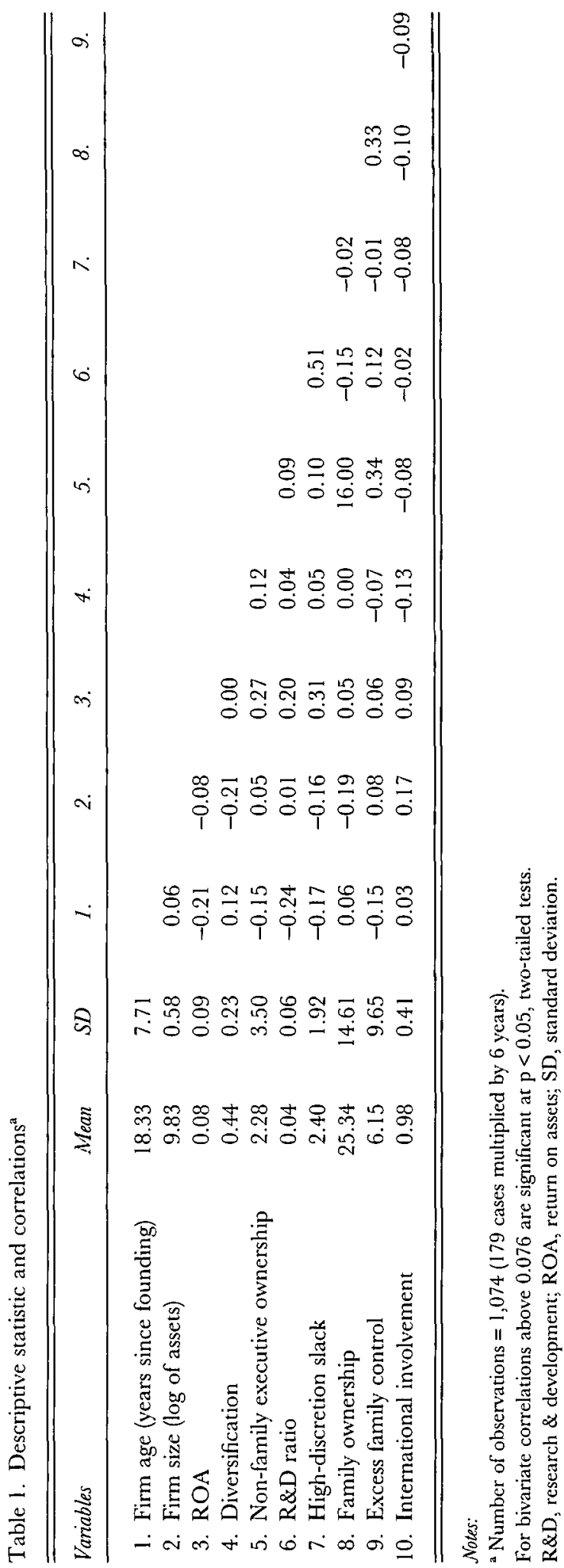

(C) 2011 The International Association for Chinese Management Rescarch 


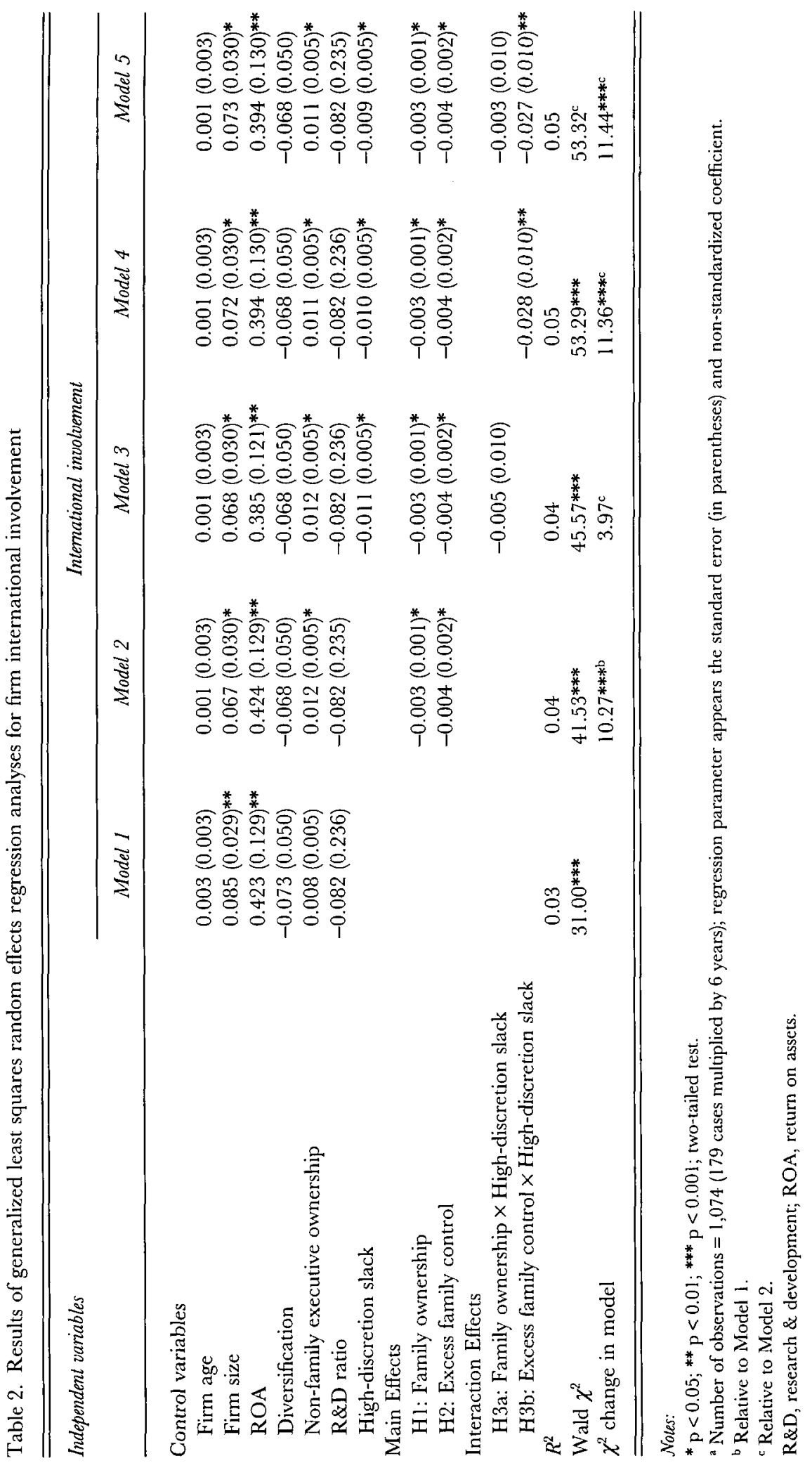


Figure 1. Moderating effects of high-discretion slack on the relationship between excess family control and international involvement

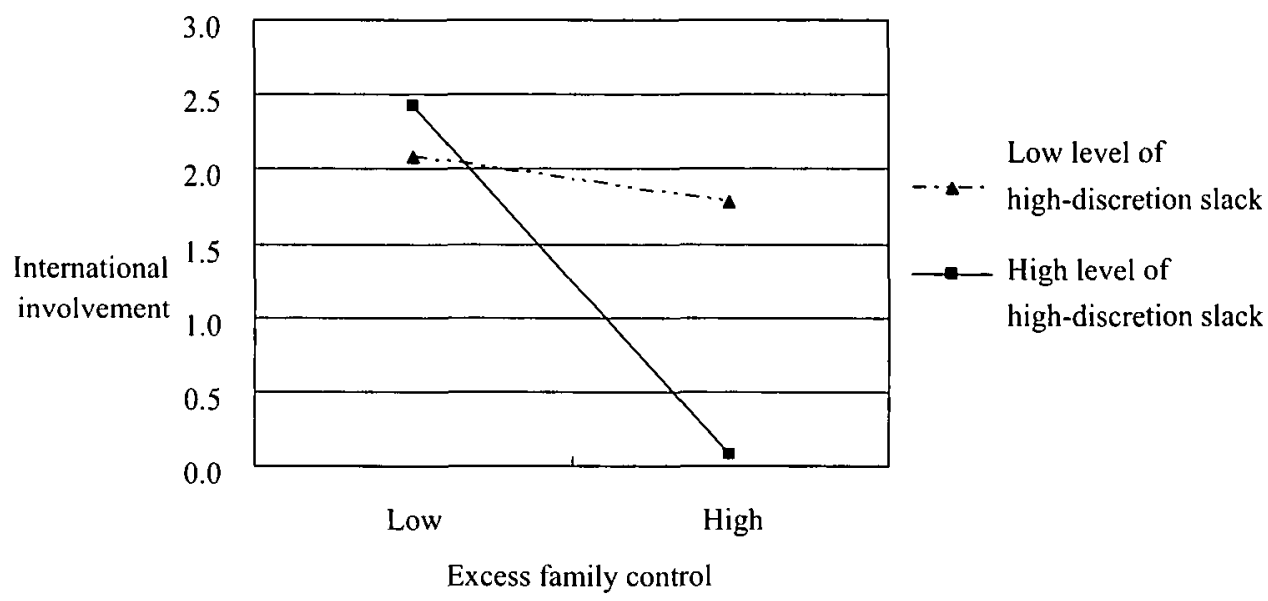

1 and 2, we found that family ownership is negatively associated with a firm's international involvement $(\beta=-0.003, p<0.05)$, thus supporting Hypothesis 1 . Consistent with Hypothesis 2, international involvement decreased significantly $(\beta=-0.004, p<0.05)$ with an increase in excess family control. Model 3 shows that the interaction effect of high-discretion slack on the relationship between family ownership and its involvement in international markets (Hypothesis $3 \mathrm{a}$ ) was not statistically significant but it was in the expected direction (Model 3; $\beta=-0.005$, n.s.). Model 4 shows that the moderating effect of high-discretion slack on the relationship between excess family control and a firm's international involvement (Hypothesis $3 b)$ is supported $(\beta=-0.028, p<0.01)$. Model 5 shows all the main and interaction effects and the results are sustained.

Figure 1 depicts the interaction of family excessive control and highdiscretionary slack. Values representing plus and minus one standard deviation from the mean of the slack variable were used to generate the plotted regression lines (Cohen, Cohen, West, \& Aiken, 2003). As illustrated in Figure 1, the negative relationship between excess family control and international involvement is stronger in firms with more high-discretion slack (plus one standard deviation from the mean) than in firms with less high-discretion slack (minus one standard deviation from the mean). A steeper negative slope clearly shows that high-discretion slack, through interaction with excess family control, has a negative effect on a firm's international involvement.

\section{DISCUSSION}

The existing research on firms' international involvement focuses on ownership structure or on human capital in developed economies (Herrmann \& Datta, 2005; 
Tihanyi et al., 2003). To better understand a firm's orientation toward internationalization in NIEs, we explore the relationship between family ownership and internationalization of firms in Taiwan's high-tech industry. We distinguish between two types of family power - family ownership and a high level of family control - to empirically test how family ownership and excess family control affect a firm's involvement in international markets. In addition, we examine the moderating influence of high-discretion organizational slack, an important factor in a firm's international involvement. Using longitudinal data (2000-2005) from Taiwan's high-tech industries, we found that family ownership and excess family control have a significantly negative relationship with a firm's international involvement. In addition, the results of the moderating effect of organizational slack support our prediction that the negative relationship between excess family control and a firm's international involvement will increase as high-discretion slack increases.

As previous studies have shown, firms that are family-owned and -managed have several specific advantages, including a long-term orientation and a family culture as a source of pride (Poza, 2004). However, these businesses also face a number of drawbacks, ranging from a lack of qualified personnel, altruism toward family members, ${ }^{[9]}$ and a tendency to be overly risk-averse (Kets De Vries, 1996). The literature and our findings suggest that family-owned and family-controlled Taiwanese high-tech firms tend to be risk-averse with regard to internationalization. The downside of a high level of family ownership and control is that the firm's ability or willingness to build a portfolio of strategic resources is limited, making it more difficult for the firm to get involved in foreign markets. In addition, our results support the notion that family-owned firms are less likely to pursue internationalization when there is more high-discretion slack. High-discretionary slack gives family members power to make self-serving decisions, including conservative international strategies. In this situation, high-discretionary slack strengthens the negative relationship between excessive family control and a firm's internationalization. Our findings support the perspective that high-discretionary organizational slack is inefficient. We contribute to the existing literature by combining the use of both organizational and economic theory to explain the relationship between family management, organizational slack, and a firm's international involvement.

\section{Limitations}

This study has three limitations. First, although our use of Taiwanese high-tech listed firms enabled us to clarify the relationships among organizational slack, family ownership, excess family control, and international involvement, our sample may have limited generalizability to other contexts (for instance, non-high-tech firms). Second, previous research uses financial measures to assess the value of organizational slack (Bourgeois \& Singh, 1983; George, 2005); however, this 
prevents us from considering non-financial and intangible slack, such as the competencies of the top management team. Third, we did not consider the variations in managerial style among family firms. Different styles of family management can lead to distinct differences in the extent of international involvement. A family firm managed by an outside (non-family) professional will be less influenced by family considerations, whereas a firm managed by a family member will be heavily influenced by family obligations.

\section{Managerial Implications}

Our findings have some interesting managerial implications for enterprises in Taiwan and perhaps in Greater China. First, by the 1990s the world had entered an era of global competition, in which national borders no longer acted as barriers. Meanwhile, Taiwan's economy also experienced a transition from local labourintensive industries to global technologically sophisticated industries. In order to make Taiwan's industries more competitive in terms of composition and exports, Taiwan has been accelerating the development of its high-tech industries. It is evident that Taiwan's high-tech firms that go international are in a better position to strategically deploy and leverage their resources. For example, we already know that participation in international production networks is critically important for the development of a flexible domestic supply base and the subsequent rapid internationalization. All high-tech firms and managers are now facing mounting pressure to compete in high risk, complex, and rapidly changing international markets. Given the recognized importance of the rapid growth of Taiwan's hightech firms, the following question should be asked: Will overly tight control of ownership and the adoption of a traditional managerial culture inhibit the ability of family-based high-tech firms to globalize? The answer based on the findings in our study is yes. The results suggest that top management teams in firms with tight family ownership and control tend to be risk-averse, resulting in a lower level of internationalization.

The traditional Chinese managerial culture of family firms that has been influenced by Confucianism encourages paternal control within the family and also promotes family collectivism and traditional respect for age, hierarchy, and authority in business. In Confucian-based cultures, family interests are valued above those of non-family interests, and decision-making tends to be centralized among family owners. Managers act on the basis of parent-child relationships and are egotistic in order to pass down their achievements and positions to the later generations; as a result, managers of Chinese family firms tend to be more risk-averse. Family businesses in Taiwan have been very successful, but this may be due to the highly centralized, tightly controlled management environment. Our study highlights the fact that family members and managers of high-tech firms will need to change to meet the demands of the increasingly global economy. Management capabilities to 
organize and leverage a firm's resources are required to successfully expand into global markets. The lack of qualified professionals and the centralized decisionmaking process in family firms may be an obstacle to successful expansion to other countries. To overcome the problem of the centralized structure and the lack of professional management in family-owned and -managed firms, family members are advised to loosen certain controls and to work with or use independent professionals to assist in seeking opportunities to improve their overall competitiveness in foreign markets. A firm that changes course and enters a foreign market might be best served by top managers from another firm. The characteristics of the new managers should differ from those of the existing management team and should focus on managing the growth process of internationalization.

Moreover, our findings may also have important implications for family-owned firms and private domestic firms in mainland China. The Chinese government currently encourages firms to expand abroad. These firms can leapfrog domestic space at an early stage because there will be lower transaction costs (Boisot \& Meyer, 2008). To achieve competitiveness, private Chinese firms can first actively move abroad. This contradicts the view of the Uppsala school that regards international strategy as an incremental learning process (Johanson \& Vahlne, 1977; Johanson \& Weidersheim-Paul, 1975). In sum, our findings may be generalizable to similar firms in mainland China. Family-owned firms or private domestic firms should engage in the 'going out' policy of the Chinese government.

Organizational slack is not only essential for the effective execution of international business opportunities, but it also serves as an effective buffer that allows firms to adjust to unanticipated foreign shocks. Nonetheless, our results show that high-discretion organizational slack may also induce inefficient behaviour on the part of management. Therefore, when developing an international strategy, owners of firms in Taiwan and possibly mainland China should be aware of the tendency to preserve their cash on hand.

\section{Future Research Implications}

With the rapid changes occurring in Greater China and other emerging markets, businesses in these markets should be an important area of study. Our findings suggest several avenues for future research. First, future research might investigate the impact of family-owned and -managed businesses on firms in other contexts, such as in different institutions or cultures. Both institutional and national culture can affect firm behaviour. For example, would the relationship between family ownership and international involvement be different among China, Korea, and Singapore, even though they are all considered to be embedded in the Confucian culture (Chai \& Rhee, 2010)? Would the 'going out' encouragement by the Chinese government overcome the inhibiting tendency of family ownership, control, and high-discretion slack? Second, future research could be extended to 
conduct more in-depth analyses of international involvement of high-technology firms such as their choices of entry mode and country destinations in order to reveal the different nature of internationalization between the asset-exploitation (Dunning, 2006) and asset-augmentation strategic motives (Mathews, 2006). In addition, researchers who can overcome the challenges of data collection in the underlying constructs of non-financial and intangible slack in the future might provide us with better insights into the relationship between a firm's organizational slack and its internationalization strategy. Finally, a related line of research might be an investigation of the implications and differences in firm internationalization between family firms owned by the original owner versus second-generation firms. This will significantly contribute to existing research on how family considerations drive a firm's decisions regarding their degree of involvement in international markets.

\section{GONGLUSION}

Strange, Filatotchev, Buck, and Wright (2009: 397) pointed out that, 'As yet, there has been little work on how different governance components impact firms' strategic decisions, such as whether, when, where, and how to internationalize, and upon how firms organize and manage their activities across national boundaries'. Based on the logic of family wealth preservation, the desire for family control, and the adoption of a traditional managerial culture, this study found that family ownership and tight family control hinder the international involvement of the high-tech firms. Moreover, organizational slack exacerbates the negative relationship between family control and firm internationalization. As high-tech firms in the NIEs increasingly engage in international activities and then become a major player in the global high-tech industry, it is important to understand how ownership, control and high-discretion organizational slack affect these firms' international involvement. We hope this study has contributed to corporate governance and international business research.

\section{NOTES}

This research was supported by NSC 94-2416-H-029-002 and NSC 96-2416-H-029-004-MY3. An carlier version was published in the top 10 percent of competitive papers proceedings 2008 of the Academy of International Business. We are grateful for the helpful comments provided by three anonymous reviewers, the Guest Editor, Professor Shaomin Li, and the Editor-in-Chief, Professor Anne S. Tsui.

[1] Data provided by the Taiwan Industry Economics Scrvice database.

[2] Using longitudinal data (2000-2005) from 631 Taiwanese electronics firms, we found that the mean for the percentage of voting rights controlled by the family is 27.36 percent.

[3] The scalc of internationalization was measured using the ratio of foreign sales and assets. Most previous studies focus on examining the effects of 'scale' on the firm's internationalization; the extent of its 'geographic dispersion' is used to gauge the extent of the firm's scope of internationalization (Thomas \& Eden, 2004). 
[4] Villalonga and Amit (2006) indicate that family ownership should be separated from family control. Family ownership is the percentage of shares of all classes held by the family as a group; in contrast, family control is the percentage of votes owned by the family in excess of the percentage of shares it owns.

[5] Most early common measures of international involvement were one-dimensional. However, one-dimensional measures are subject to various problems, including failure to reflect the breadth and depth of international involvement simultaneously. To resolve these shortcomings, researchers have adopted a multi-dimensional approach (c.g., Lu \& Beamish, 2004; Sullivan, 1994).

[6] A structural attribute consists of two items: foreign assets as a percentage of total assets and overseas subsidiaries as a percentage of total subsidiaries.

[7] These variables were loaded on a factor using the 'principal component extraction' method and 'varimax rotation'.

[8] The numerator includes all shares held by family representatives (e.g., family-designated directors). It includes all shares in which any family member has a shared investment or voting power with another family member (which are only counted once), but it docs not include any of the shares where the investment or voting power is shared with a non-member of the family.

[9] Altruism means that the individual is allowed to satisfy both altruistic (other-regarding) and egotistic (self-regarding) preferences simultaneously (Schulze et al., 2001).

\section{REFERENCES}

Ahlstrom, D., Young, M. N., Ng, F. M. C., \& Chan, C. M. 2004. High technology and globalization challenges facing overseas Chincse entrepreneurs. Sam Advanced Management Journal, 69(2): $28-37$.

Aiken, L. S., \& West, S. G. 1991. Multiple regression: Testing and interpreting interactions. Newbury Park, CA: Sage.

Anderson, R. C., \& Reeb, D. M. 2003. Founding family ownership and firm performance: Evidence from the S\&P 500. Joumal of Finance, 58(3): 1301-1327.

Araujo, L., \& Rezende, S. 2003. Path dependence, MNCs and the internationalization process: A rclational approach. International Business Revieze, 12(6): 719-737.

Baker, T., \& Nelson, R. E. 2005. Creating something from nothing: Resource construction through entrepreneurial bricolage. Administrative Science Quarterly, 50(3): 329-366.

Bartlett, C. A., \& Ghoshal, S. 1989. Managing across borders: The transnational solution. Boston, MA: Harvard Business School Press.

Begley, T. M., \& Tan, W. L. 2001. The socio-cultural environment for entrepreneurship: A comparison between East Asian and Anglo-Saxon countries. Joumal of Intermational Business Studies, 32(3): 537-553.

Boisot, M., \& Meyer, M. W. 2008. Which way through the open door? Reflections on the internationalization of Chinese firms. Management and Organization Reviez, 4(3): 349365.

Bourgeois, L. J. 1981. On the measurement of organizational slack. Academy of Management Revieze, 6(1): 29-39.

Bourgeois, L. J., \& Singh, J. V. 1983. Organizational slack and political behavior within top management tcams. Academy of Management Proceedings 43-47.

Bruton, G., Ahlstrom, D., \& Wan, J. 2003. Turnaround in East Asian firms: Evidence from ethnic overscas Chinesc communities. Strategic Management Journal, 24(6): 519-540.

Carney, M. 1998. A management capacity constraint? Barricrs to the development of the Chinese family business. Asia Pacific Journal of Management, 15(2): 137-162.

Carney, M. 2005. Corporate governance and competitive advantage in family-controlled firms. Entrepreneurship Theory and Practice, 29(3): 249-265.

Carpenter, M. A., \& Fredrickson, J. W. 2001. Top management teams, global strategic posture, and the moderating role of uncertainty. Academy of Management Joumal, 44(3): 533545.

Chai, S. K., \& Rhec, M. 2010. Confucian capitalism and the paradox of closure and structural holes in East Asian firms. Management and Organization Revieze, 6(1): 5-29.

Chandler, A. D. 1990. Scale and scope: The dynamics of industrial competition. Cambridge, MA: Harvard University Press. 
Chang, S. C. 2007. The interactions among foreign direct investments, economic growth, degree of openness and unemployment in Taiwan. Applied Economics, 39(13): 1647-1661.

Chen, M. 2001. Inside Chinese business: A guide for managers world zide. Boston, MA: Harvard Business School Press.

Claessens, S., Djankov, S., \& Lang, L. H. P. 2000. The separation of ownership and control in East Asian corporations. Joumal of Financial Economics, 58(1-2): 81-112.

Clacssens, S., Djankov, S., Fan, J. P. H., \& Lang, L. H. P. 2002. Disentangling the incentive and entrenchment effects of large shareholdings. Journal of Finance, 57(6): 2741-2771.

Cohen, J., Cohen, P., West, S., \& Aiken, L. 2003. Applied multiple regression/correlation analysis for the behavioral sciences (3rd ed.). Mahwah, NJ: Lawrence Erlbaum Associates.

Contractor, F.J., Kumar, V., \& Kundu, S. K. 2007. Nature of the relationship between international expansion and performance: The case of emerging market firms. Journal of World Business, 42(4): $401-417$.

Cyert, R., \& March, J. 1963. The behavioral theory of the firm. Englewood Cliffs, NJ: Prentice Hall.

Daniels, J., \& Bracker, J. 1989. Profit performance: Do foreign operations makc a difference. Management International Review, 29(1): 46-56.

Donckels, R., \& Frohlich, E. 1991. Are family businesses really different? European cxperiences from STRATOS. Family Business Review, 4(2): 149-160.

Dunning, J. 2006. Comment on dragon multinationals: New players in 21 st century globalization. Asia Pacific Joumal of Management, 23(2): 139-141.

Erdener, C., \& Shapiro, D. M. 2005. The internationalization of Chinese family enterprises and Dunning's eclectic MNE paradigm. Management and Organization Review, 1(3): 411436.

Fama, E., \& Jensen, M. 1983. Separation of ownership and control. Journal of Laze and Economics, 26(2): $301-325$.

Fama, E., \& Jensen, M. 1985. Organizational forms and investment decisions. Journal of Financial Economics, 14(1): 101-119.

Femández, Z., \& Nieto, N.J. 2006. Impact of ownership on the international involvement of SMEs. Journal of Intemational Business Studies, 37(3): 340-351.

Filatotchev, I., \& Piesse, J. 2009. R\&D, internationalization and growth of newly listed firms: European evidence. Journal of Intemational Business Studies, 40(8): 1260-1276.

Filatotchev, I., Lien, Y. C., \& Piesse, J. 2005. Corporate governance and performance in publicly listed, family-controlled firms: Evidence from Taivan. Asia Pacific Joumal of Management, 22(3): 258-283.

Filatotchev, I., Strange, R., Piesse, J., \& Lien, Y. C. 2007. FDI by firms from newly industrialised economies in emerging markets: Corporate governance, entry mode and location.Joumal of International Business Studies, 38(4): 556-572.

George, G. 2005. Slack resources and the performance of privately held firms. Academy of Management Journal, 48(4): 661-676.

George, G., Wiklund, J., \& Zahra, S. A. 2005. Ownership and the internationalization of small firms. Journal of Management, $31(2)$ : 210-233.

Geringer, J., Beamish, P., \& da Costa, R. 1989. Diversification strategy and internationalization: Implications for MNE performance. Strategic Management Journal, 10(2): 109-119.

Graves, C., \& Thomas, J. 2006. Internationalization of Australian family business: A managerial capabilities perspective. Family Business Reviez, 19(3): 207-224.

Grecne, W. H. 2000. Econometric analysis (4th ed.). Englewood Cliffs, NJ: Prentice Hall.

Henderson, A. D., \& Fredrickson, J. W. 1996. Information-processing demands as a determinant of CEO compensation. Academy of Management Joumal, 39(3): 575-606.

Herrmann, P., \& Datta, D. K. 2005. Relationships between top management team characteristics and international diversification: An empirical investigation. British Joumal of Management, 16(1): 69-78.

Hitt, M. A., Bierman, L., Uhlenbruck, K., \& Shimizu, K. 2006. The importance of resources in the internationalization of professional service firms: The good, the bad, and the ugly. Academy of Management Joumal, 49(6): 1137-1 157.

Hitt, M. A., Tihanyi, L., Miller, T., \& Connelly, B. 2006. International diversification: Antecedents, outcomes, and moderators. Journal of Management, 32(6): 831-867. 
Hordes, M., Clancy, J., \& Baddaley, J. 1995. A primer for global start-ups. Academy of Management Executive, 9(2): 7-11.

Javidan, M., \& House, R. J. 2002. Leadership and cultures around the world: Findings from global. Journal of World Business, 37(1): 1-2.

Jensen, M. C., \& Meckling, W. H. 1976. Theory of the firm: Managerial behavior, agency costs, and ownership structure. Joumal of Financial Economics, 3(4): 305-360.

Johanson, J., \& Vahlne, J. E. 1977. The internationalization process of the firm - A model of knowledge development and increasing foreign market commitments. Journal of International Business Studies, 8(1): 23-32.

Johanson, J., \& Weidersheim-Paul, J. 1975. The internationalization of the firm: Four Swedish case studies. Journal of Management Studies, 12(3): 305-323.

Kets De Vries, M. 1996. Family business: Human dilemmas in the family firm. London: Thomson Business Press.

Kim, H., Kim, H., \& Lee, P. M. 2008. Ownership structure and the relationship between financial slack and R\&D investments: Evidence from Korean firms. Organization Science, 19(3): 404-418.

La Porta, R., Lopez-de-Silanes, F., \& Schleifer, A. 1999. Corporate ownership around the world. Joumal of Finance, 54(2): 471-516.

Levinthal, D. A. 1997. Adaptation on rugged landscapes. Management Science, 43(7): $934-$ 950.

Lien, Y.-C., Piesse, J., Strange, R., \& Filatotchev, I. 2005. The role of corporate governance in FDI decisions: Evidence from Taiwan. International Business Reviezv, 14(6): 739-773.

Lins, K. V. 2003. Equity ownership and firm value in emerging markets. Journal of Financial and Quantitative Analysis, 38(1): 159-184.

Lu, J. W., \& Beamish, P. W. 2001. The internationalization and performance of SMEs. Strategic Management Joumal, 22(6-7): 565-586.

Lu, J. W., \& Beamish, P. W. 2004. International diversification and firm performance: The S-curve hypothesis. Academy of Management Journal, 47(4): 598-609.

Lu, J., Liu, X., \& Wang, H. 2011 . Motives for outward FDI of Chinese private firms: Firm resources, industry dynamics, and government policies. Management and Organization Revieze, $7(2): 223-248$.

MacMillan, I. C., \& McGrath, R. G. 1997. What is strategy? Harvard Business Reviere, 75(1): $154-156$.

Mathews, J. A. 2006. Dragon multinationals: New players in the 21 st century globalization. Asia Pacific Joumal of Management, 23(1): 5-27.

Maug, E. 1998. Large shareholders as monitors: Is there a trade-off between liquidity and control? Journal of Finance, 53(1): 65-98.

Mustcen, M., Datta, D. K., \& Herrmann, P. 2009. Ownership structure and CEO compensation: Implications for the choice of forcign market entry modes. Journal of International Business Studies, 40(2): 321-338.

Poza, E. 2004. Family business. Mason, OH: Thomson South-Western Publishing.

Ramamurti, R. 2004. Developing countries and MNEs: Extending and enriching the research agenda. Joumal of International Business Studies, 35(4): 277-283.

Sanders, W. G., \& Carpenter, M. A. 1998. Internationalization and firm governance: The roles of CEO compensation, top team composition, and board structure. Academy of Management Journal, 41(2): 158-178.

Sapienza, H.J., Autio, E., George, G., \& Zahra, S. A. 2006. A capabilities perspective on the effects of early internationalization on firm survival and growth. Academy of Management Reviez, 31(3): 914-933.

Schulze, W. S., Lubatkin, M. H., Dino, R. N., \& Buchholtz, A. K. 2001. Agency relationships in family firms: Theory and evidence. Organization Science, 12(2): 99-116.

Sharfman, M., Wolf, G., Chase, R., \& Tansik, D. 1988. Antecedents of organizational slack. Academy of Management Reviez, 13(4): 601-614.

Smith, K., Grimm, C., Gannon, M., \& Chen, M. 1991. Organizational information processing: Competitive responses and performance in the U.S. domestic airline industry. Academy of Management Journal, 34(1): 60-85.

Strange, R., Filatotchev, I., Buck, T., \& Wright, M. 2009. Corporate governance and international business. Management International Review, 49(4): 395-407. 
Sullivan, D. 1994. Measuring the degree of internationalization of a firm. Journal of Business Studies, 25(2): 325-342.

Sullivan, D., \& Bauerschmidt, A. 1989. Common factors underlying barriers to export: A comparative study in the European and U.S. paper industry. Management Intemational Revieze, 29(2): 46-63.

Thomas, D. E., \& Eden, L. 2004. What is the shape of the multinational-performance relationship? The Multinational Business Reviez, 12(1): 89-110.

Tihanyi, L., Ellstrand, A. E., Daily, C. M., \& Dalton, D. R. 2000. Composition of the top management team and firm international diversification. Journal of Management, 26(6): 11571177.

Tihanyi, L., Johnson, R. A., Hoskisson, R. E., \& Hitt, M. A. 2003. Institutional ownership differences and international diversification: The effects of boards of directors and technological opportunity. Academy of Management Joumal, 46(2): 195-211.

Villalonga, B., \& Amit, R. 2006. How do family ownership, control and management affect firm value? Journal of Financial Economics, 80(2): 385-417.

Yeh, K. S., \& Tsao, L. C. 1996. Jiazhu Qiyei Jieban Gwuizhen zhi Wanlu Fenxi [A network analysis of ownership succession in family owned businesses]. Guan ka Shaiboze [Joumal of Management Science], 13(2): 197-225.

Yeh, Y. H., Lee, T. S., \& Woidtke, T. 2001. Family control and corporate governance: Evidence from Taiwan. International Revieze of Finance, 2(12): 21-48.

Yip, G. S., Biscarri, J. G., \& Monti, J. A. 2000. The role of the internationalization process in the performance of newly internationalizing firms. Journal of International Marketing, 8(3): $10-35$.

Zahra, S. A. 2003. International expansion of U.S. manufacturing family businesses: The effect of ownership and involvement. Journal of Business Venturing, 18(4): 495-512.

Zahra, S. A. 2005. Entrepreneurial risk taking in family firms. Family Business Revieze, 18(1): 23-40.

Yunshi Liu (liuys@yuntech.edu.tw) is Associate Professor of Business Administration at the National Yunlin University of Science \& Technology. She received her Ph.D. from National Sun Yat-Sen University in 1998 with a major in organization management. Her recent research interests focus on corporate governance, top management succession, organizational change, and interlocking directorate. Her research has been published in Intermational Business Reviere, Journal of World Business, Joumal of International Management, European Joumal of International Management, Journal of Management (Chinese), and Sun Yat-Sen Management Reviezo (Chinese).

Wen-Ting Lin (wentinglin@ccu.edu.tw) is an Assistant Professor of the Department of Business Administration in the College of Management at National Chung Cheng University. She received her Ph.D. in international business management from National Taiwan University. Her research interests include international business management, organizational theory, and corporate governance. Her research has been published in Joumal of International Management, European Journal of International Management, Journal of World Business, International Journal of Human Resource Management, and Sun Yat-Sen Management Review (Chinese). Corresponding author. 
Kuei-Yang Cheng (d94724015@ntu.edu.tw) is a Ph.D. candidate in International Business at National Taiwan University, Taiwan. Her main research interests include the relationship between the determinants and effects of foreign direct investment, international strategy, and multinational enterprises in emerging economies. Her research has been published in Journal of International Management and Joumal of World Business.

Manuscript received: May 1, 2009

Final version accepted: March 31, 2011

Accepted by:

Shaomin Li 